\title{
KONTROL OPTIMAL MENGGUNAKAN PRINSIP MINIMUM PONTRYAGIN PADA MODEL PENYEBARAN PENYAKIT TUBERKULOSIS DI KALIMANTAN BARAT
}

\author{
FAJRIN NURSETYA DESI, EVI NOVIANI, YUDHI* \\ Program Studi S1 Matematika,
}

Fakultas Matematika dan Ilmu Pengetahuan Alam, Universitas Tanjungpura, Pontianak email :fajrinursetyadesi@gmail.com,evi_noviani@math.untan.ac.id,yudhi@math.untan.ac.id

\begin{abstract}
Abstrak. Penyakit Tuberkulosis (TB) disebabkan karena bakteri mycrobacterium tuberculosis dan merupakan penyakit menular yang mempengaruhi paru-paru. Di Kalimantan Barat tercatat jumlah kasus baru TB sebanyak 3.463 kasus dengan angka insidens 70, 21 per 100.000 penduduk. Sedangkan dengan persentase kesembuhan $67,5 \%$ pasien TB paru dinyatakan sembuh, dengan rincian dari 3611 pasien yang mendapatkan pengobatan, sebanyak 2436 pasien yang sembuh. Dengan pemberian vaksinasi dan pengobatan penularan penyakit TB dapat dicegah. Pada penelitian ini, model epidemi dibagi menjadi tiga subpopulasi, yaitu subpopulasi Susceptible (S), subpopulasi Infectious (I) dan subpopulasi Recovered (R). Dari ketiga subpopulasi tersebut kemudian dibentuk model epidemi tipe SIR. Untuk menekan penularan, sistem diberikan kontrol, yaitu vaksinasi $\left(u_{1}\right)$ pada bayi yang baru lahir dan kontrol pengobatan $\left(u_{2}\right)$ diberikan pada individu infective yang melakukan kontak langsung dengan individu susceptible. Tujuan pemberian kontrol tersebut adalah untuk mengurangi jumlah individu susceptible dan individu infective. Model epidemi SIR yang sudah diberikan kontrol $\left(u_{1}\right)$ dan $\left(u_{2}\right)$, diselesaikan dengan Prinsip Minimum Pontryagin untuk mendapatkan suatu kontrol optimal $u_{1}^{*}$ dan $u_{2}^{*}$. Berdasarkan simulasi numerik yang telah dilakukan didapatkan hasil yaitu kontrol bekerja secara efektif dalam menekan penyebaran TB sehingga individu infective berkurang.

Kata Kunci: Tuberkulosis, Model SIR, Kontrol Optimal, Prinsip Minimum Pontryagin
\end{abstract}

\section{Pendahuluan}

Penyakit Tuberkulosis (untuk selanjutnya disingkat TB), adalah penyakit menular yang mematikan yang menyerang paru-paru [1]. Penyakit TB dapat menyebar ketika bakteri mycrobacteriun tuberculosis tersebar ke udara dari penderita TB, misalnya dengan batuk. Solusi untuk permasalahan penyebaran penyakit TB tersebut adalah dengan menerjemahkan masalah tersebut ke model matematika. Program vaksinasi adalah salah satu upaya untuk mencegah menularnya penyakit TB tersebut.

*penulis korespondensi 
Kontrol yang diberikan adalah kontrol vaksinasi dan pengobatan dalam upaya mengurangi jumlah individu yang terinfeksi penyakit TB. Penyelesaian kontrol optimal tersebut diselesaikan dengan Prinsip Minimum Pontryagin, yaitu untuk mendapatkan kontrol optimal pada sistem dinamik, dari state awal sampai akhir, dengan mengoptimalkan fungsi tujuan $J$ yang menggunakan kontrol $u$ [2].

Penyebaran penyakit tuberkulosis dapat dianalisis menggunakan model matematika yaitu model SIR. Fredlina dkk. [3] telah melakukan pemodelan untuk penyebaran penyakit tuberkulosis dengan model SIR. Selanjutnya, Utari [4] telah melakukan penelitian untuk menentukan bentuk kontrol yang optimal yang dapat menekan laju pertambahan jumlah individu yang terinfeksi. Kemudian, Anggraini dkk. [5] mengemukakan bahwa kontrol vaksinasi dan pengobatan menunjukkan keefektifan dalam pengendalian populasi yang terinfeksi. Tujuan dari penelitian ini adalah membentuk model epidemi tipe SIR dengan penambahan kontrol vaksinasi dan pengobatan pada penyebaran penyakit TB dan mendapatkan kontrol yang optimal dari model epidemi tipe SIR.

\section{Landasan Teori}

\subsection{Teori Kontrol Optimal}

Teori kontrol optimal diperlukan dalam penelitian ini karena bersesuaian dengan tujuan penelitian. Tujuan dari kontrol optimal adalah untuk mendapatkan nilai kontrol yang selanjutnya di substitusikan kedalam model dan memenuhi kendala. Nilai minimum dan maksimum dapat ditentukan dalam waktu yang sama sesuai dengan fungsi tujuan [2]. Masalah kontrol optimal secara umum dapat dirumuskan sebagai berikut,

$$
\dot{x}=f(x(t), u(t), t)
$$

dengan fungsi $f=\left(f_{1}, f_{2}, \cdots, f_{n}\right)$, variabel $x=\left(x_{1}, x_{2}, \cdots, x_{n}\right)$, kontrol keadaan pada waktu $t$ yaitu $u(t)$, keadaan awal pada waktu $t_{0}$ yaitu $x\left(t_{0}\right)=x_{0}$, dan keadaan akhir pada waktu $t_{f}$ yaitu $x\left(t_{f}\right)=x_{f}$. Dalam penelitian ini, masalah kontrol optimal yaitu mendapatkan suatu kontrol optimal $u^{*}(t)$ yang memenuhi persamaan (state) dengan syarat nilai $J$ yaitu,

$$
J=S\left(x\left(t_{f}\right), x_{f}\right)+\int_{t_{0}}^{t} V(x(t), u(t), t) d t .
$$

Bentuk umum $J$ pada persamaan (2.2) yang memuat $S$ dan $V$ disebut fungsi tujuan bentuk Bolza. Ketika fungsi tujuan $J$ pada persamaan (2.2) tidak memuat $S$ maka fungsi tujuan tersebut disebut bentuk Lagrange. Jika fungsi tujuan $J$ pada persamaan (2.2) tidak memuat $V$ maka fungsi tujuan tersebut disebut bentuk Meyer. Selanjutnya, untuk mendapatkan kontrol optimal pada model epidemi tipe SIR menggunakan Prinsip Minimum Pontryagin.

\subsection{Prinsip Minimum Pontryagin}

Prinsip Minimum Pontryagin adalah suatu kondisi untuk menyelesaikan kontrol optimal yang sesuai dengan fungsi tujuan. Fungsi tujuan yang dibentuk menyatakan 
jumlah individu yang terinfeksi dan biaya vaksinasi serta pengobatan yang dilakukan. Berdasarkan fakta keterkaitan antara biaya vaksinasi dan pengobatan dengan jumlah individu yang terinfeksi memiliki hubungan tidak linier, maka dipilih fungsi kuadratik $u^{2}(t)$ untuk meminimumkan jumlah individu yang terinfeksi dan meminimumkan energi [6], sehingga fungsi tujuan dibentuk sebagai berikut:

$$
J\left(u_{1}, u_{2}\right)=\int_{0}^{t_{f}}\left[I(t)+\frac{c_{1}}{2} u_{1}^{2}(t)+\frac{c_{2}}{2} u_{2}^{2}(t)\right] d t,
$$

dengan $c_{1}$ adalah biaya untuk vaksinasi, $c_{2}$ adalah biaya untuk pengobatan, dan $t_{f}$ adalah waktu akhir periode.

\section{Pembahasan}

\subsection{Pemodelan Penyakit TB dengan Penambahan Kontrol}

Penelitian ini menggunakan model SIR dan populasi dibagi menjadi tiga bagian, yaitu susceptible, infective, dan recovered.

Berikut ini adalah diagram transfer model epidemi tipe SIR dengan penambahan kontrol vaksinasi dan pengobatan.

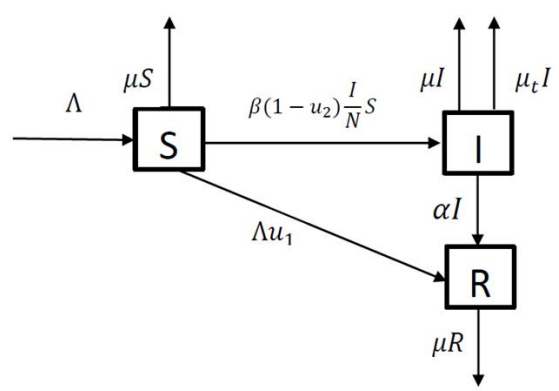

Gambar 1. Diagram alir model SIR dengan penambahan kontrol vaksinasi dan pengobatan untuk penyebaran penyakit TB

Berdasarkan Gambar 1, Sub-populasi susceptible bertambah dengan banyaknya kelahiran sebesar $\Lambda$ dan berkurang karena adanya tingkat kematian alami $\mu$, sehingga sub-populasi susceptible akan berkurang sebesar $(\mu S)$. Individu yang baru lahir diberi vaksinasi $\left(u_{1}\right)$, sehingga sub-populasi susceptible akan berkurang karena adanya jumlah individu lahir yang diberikan vaksinasi $\left(\Lambda u_{1}\right)$ dan juga dipengaruhi oleh proporsi banyaknya individu infective yang melakukan kontak langsung dengan individu susceptible sebesar $\frac{I}{N}$, dan laju penginfeksian sebesar $\beta$, sehingga untuk mengurangi tingkat infeksi tersebut diberikan kontrol pengobatan sebesar $\left(1 u_{2}\right)$.

Proporsi banyaknya individu infective yang melakukan interaksi langsung dengan individu susceptible $\frac{I}{N}$ menyebabkan individu infective bertambah. Berkurangnya jumlah individu infective disebabkan karena kematian alami $\mu$ dan kematian akibat penyakit $\mu_{t}$. Individu infective yang sembuh secara spontan karena daya 
tahan tubuh yang kuat juga menyebabkan berkurangnya jumlah individu infective $(\alpha I)$ dan masuk kedalam sub-populasi recovered.

Bertambahnya individu recovered dipengaruhi oleh adanya individu infective yang sembuh secara spontan $(\alpha I)$ dan banyaknya kelahiran yang diberi vaksinasi $\left(\Lambda u_{1}\right)$. Individu recovered mengalami kematian alami dengan parameter $\mu$, sehingga $\mu R$ menyatakan berkurangnya sub-populasi recovered.

Berdasarkan uraian tersebut, maka didapat suatu model penyebaran penyakit Tuberkulosis dengan penambahan kontrol sebagai berikut.

$$
\begin{aligned}
& \frac{d S}{d t}=\Lambda-\Lambda u_{1}-\beta\left(1-u_{2}\right) \frac{I}{N} S-\mu S, \\
& \frac{d I}{d t}=\beta\left(1-u_{2}\right) \frac{I}{N} S-\mu I-\mu_{t} I-\alpha I, \\
& \frac{d R}{d t}=\Lambda u_{1}+\alpha I-\mu R,
\end{aligned}
$$

dengan

$$
\begin{aligned}
S & : \text { jumlah individu susceptible, } \\
I & : \text { jumlah individu infective, } \\
R & : \text { jumlah individu recovered, } \\
N & : \text { total populasi, } \\
\Lambda & : \text { jumlah kelahiran alami, } \\
\mu & : \text { laju kematian alami, } \\
\mu_{t} & : \text { laju kematian akibat penyakit, } \\
\alpha & : \text { laju kesembuhan alami, } \\
\beta & : \text { laju penularan penyakit, } \\
u_{1} & : \text { laju kontrol dengan vaksinasi, } \\
u_{2} & : \text { laju kontrol dengan pengobatan. }
\end{aligned}
$$

Dari Persamaan (3.1) selanjutnya akan diselesaikan permasalahan kontrol optimal.

\subsection{Penyelesaian Persamaan (3.1) Untuk Mendapatkan Kontrol Optimal}

Langkah-langkah yang dilakukan untuk mendapatkan kontrol optimal yaitu:

(1) Membentuk fungsi Hamiltonian $(H)$.

$$
\begin{aligned}
H(x, u, t, \lambda)= & V(x, u, t)+\sum_{i=1}^{3} \lambda_{i}(t) f_{i}(x, u, t), \\
= & I(t)+\frac{c_{1}}{2} u_{1}^{2}(t)+\frac{c_{2}}{2} u_{2}^{2}(t)+\lambda_{1}\left(\Lambda-\Lambda u_{1}-\beta\left(1-u_{2}\right) \frac{I}{N} S-\mu S\right) \\
& +\lambda_{2}\left(\beta\left(1-u_{2}\right) \frac{I}{N} S-\mu I-\mu_{t} I-\alpha I\right)+\lambda_{3}\left(\Lambda u_{1}+\alpha I-\mu R\right)
\end{aligned}
$$


(2) Meminimumkan $H$ terhadap $u(t)$.

$$
\begin{gathered}
\frac{\partial H}{\partial u_{1}(t)}=0, \\
\frac{\partial H}{\partial u_{2}(t)}=0 .
\end{gathered}
$$

Sehingga diperoleh

$$
\begin{aligned}
& \left(\frac{\partial H}{\partial u_{1}(t)}\right)^{*}=c_{1} u_{1}(t)-\lambda_{1} \Lambda+\lambda_{3} \Lambda, \\
& \left(\frac{\partial H}{\partial u_{2}(t)}\right)^{*}=c_{2} u_{2}(t)+\lambda_{1} \beta \frac{I}{N} S-\lambda_{2} \beta \frac{I}{N} S .
\end{aligned}
$$

Selanjutnya dicari nilai $u_{1}(t)$ dan $u_{2}(t)$ sehingga didapatkan kontrol sebagai berikut.

$$
\begin{aligned}
& u_{1}(t)=\frac{\lambda_{1} \Lambda-\lambda_{3} \Lambda}{c_{1}}=\left(\lambda_{1}-\lambda_{3}\right) \frac{\Lambda}{c_{1}}, \\
& u_{2}(t)=\frac{-\lambda_{1} \beta \frac{I}{N} S+\lambda_{2} \beta \frac{I}{N} S}{c_{2}}=\left(\lambda_{2}-\lambda_{1}\right) \frac{\beta I S}{c_{2} N} .
\end{aligned}
$$

Karena nilai kontrolnya terbatas, dimana $0 \leq u_{1}(t), u_{2}(t) \leq 1$, maka

$$
\begin{aligned}
& u_{1}^{*}(t)= \begin{cases}0, & u_{1}(t) \leq 0, \\
u_{1}(t), & 0<u_{1}(t) \leq 1, \\
1, & u_{1}(t) \geq 0\end{cases} \\
& u_{2}^{*}(t)= \begin{cases}0, & u_{2}(t) \leq 0, \\
u_{1}(t), & 0<u_{2}(t) \leq 1, \\
1, & u_{2}(t) \geq 0,\end{cases}
\end{aligned}
$$

Dari persamaan (3.3) dan (3.3) nilai $u_{1}^{*}(t)$ dan $u_{2}^{*}(t)$ dapat dituliskan dalam bentuk:

$$
\begin{aligned}
& u_{1}^{*}(t)=\min \left\{1 ; \max \left\{0, \frac{\lambda_{1} \Lambda-\lambda_{3} \Lambda}{c_{1}}\right\}\right\}, \\
& u_{2}^{*}(t)=\min \left\{1 ; \max \left\{0, \frac{-\lambda_{1} \beta \frac{I}{N} S+\lambda_{2} \beta \frac{I}{N} S}{c_{2}}\right\}\right\} .
\end{aligned}
$$

(3) Mengoptimalkan fungsi Hamiltonian $\left(H^{*}\right)$.

Dengan mensubstitusikan $u^{*}$ yang telah didapat pada langkah (2) ke bentuk Hamiltonian:

$$
\begin{aligned}
& H^{*}\left(S^{*}(t), I^{*}(t), R^{*}(t), u_{1}^{*}, u_{2}^{*}, \lambda\right) \\
= & I(t)+\frac{c_{1}}{2} u_{1}^{2}(t)+\frac{c_{2}}{2} u_{2}^{2}(t)+\lambda_{1}\left(\Lambda-\Lambda u_{1}^{*}-\beta\left(1-u_{2}^{*}\right) \frac{I(t)}{N} S(t)-\mu S(t)\right) \\
& +\lambda_{2}\left(\beta\left(1-u_{2}^{*}\right) \frac{I(t)}{N} S(t)-\mu I(t)-\mu_{t} I(t)-\alpha I(t)\right) \\
& +\lambda_{3}\left(\Lambda u_{1}^{*}+\alpha I(t)-\mu R(t)\right) .
\end{aligned}
$$


(4) Mencari persamaan state dan co-state.

Untuk mendapatkan kedua persamaan tersebut adalah sebagai berikut.

(a) Persamaan state

$$
\begin{aligned}
& \dot{x_{1}}(t)=\frac{\partial H}{\partial \lambda_{1}}=\Lambda-\Lambda u_{1}-\beta\left(1-u_{2}\right) \frac{I}{N} S-\mu S, \\
& \dot{x_{2}}(t)=\frac{\partial H}{\partial \lambda_{2}}=\beta\left(1-u_{2}\right) \frac{I}{N} S-\mu I-\mu_{t} I-\alpha I, \\
& \dot{x_{3}}(t)=\frac{\partial H}{\partial \lambda_{3}}=\Lambda-\Lambda u_{1}+\alpha I-\mu R,
\end{aligned}
$$

(b) Persamaan co-state

$$
\begin{aligned}
& \dot{\lambda_{1}}(t)=-\frac{\partial H}{\partial S}=\lambda_{1} \beta\left(1-u_{2}\right) \frac{I}{N}+\lambda_{1} \mu-\lambda_{2} \beta\left(1-u_{2}\right) \frac{I}{N}, \\
& \dot{\lambda_{2}}(t)=-\frac{\partial H}{\partial I}=\lambda_{1} \beta\left(1-u_{2}\right) \frac{S}{N}-\lambda_{2} \beta\left(1-u_{2}\right) \frac{S}{N}+\lambda_{2} \mu+\lambda_{2} \mu_{t}+\lambda_{2} \alpha-\lambda_{3} \alpha-1 \\
& \dot{\lambda_{3}}(t)=\frac{\partial H}{\partial R}=\lambda_{3} \mu .
\end{aligned}
$$

dengan kondisi transversal $\lambda_{1}\left(t_{f}\right)=0, \lambda_{2}\left(t_{f}\right)=0, \lambda_{3}\left(t_{f}\right)=0$.

(5) Mendapatkan kontrol optimal yang dicari.

Substitusikan hasil yang diperoleh dari langkah (4) ke persamaan $u^{*}(t)$ pada langkah (2):

$$
\begin{aligned}
\frac{d S}{d t} & =\Lambda-\Lambda u_{1}^{*}-\beta\left(1-u_{2}^{*}\right) \frac{I}{N} S-\mu S \\
\frac{d I}{d t} & =\beta\left(1-u_{2}^{*}\right) \frac{I}{N} S-\mu I-\mu_{t} I-\alpha I \\
\frac{d R}{d t} & =\Lambda u_{1}^{*}+\alpha I-\mu R \\
\dot{\lambda_{1}}(t) & =\lambda_{1} \beta\left(1-u_{2}^{*}\right) \frac{I}{N}+\lambda_{1} \mu-\lambda_{2} \beta\left(1-u_{2}^{*}\right) \frac{I}{N} \\
\dot{\lambda_{2}}(t) & =\lambda_{1} \beta\left(1-u_{2}^{*}\right) \frac{S}{N}-\lambda_{2} \beta\left(1-u_{2}^{*}\right) \frac{S}{N}+\lambda_{2} \mu+\lambda_{2} \mu_{t}+\lambda_{2} \alpha-\lambda_{3} \alpha-1 \\
\dot{\lambda_{3}}(t) & =\frac{\partial H}{\partial R}=\lambda_{3} \mu
\end{aligned}
$$

dengan kondisi batas $S(0)=S_{0}, I(0)=I_{0}, R(0)=R_{0}, \lambda_{1}\left(t_{f}\right)=0, \lambda_{2}\left(t_{f}\right)=$ $0, \lambda_{3}\left(t_{f}\right)=0$.

Setelah diperoleh hasil dari Prinsip Minimum Pontryagin, selanjutnya menyelesaikan hasil tersebut dengan simulasi numerik. Metode yang digunakan dalam penyelesaian numerik adalah Runge Kutta orde 4. Langkah pertama untuk penyelesaian numerik adalah mentransformasikan persamaan state dan co state dalam bentuk diskrit. 


\subsection{Proses Diskritisasi Sistem Persamaan}

Persamaan state yang terdapat pada Persamaan (3.5) diselesaikan menggunakan skema maju Runge Kutta orde 4 . Misalkan $n$ adalah banyaknya iterasi dengan index $i$ dan $i=0,1,2, \cdots, n$, dengan total populasi adalah $N, N_{i}$ adalah total populasi ke- $i, S_{i}$ adalah sub populasi Susceptible ke- $i, I_{i}$ adalah sub populasi Infective ke- $i$, dan $R_{i}$ adalah sub populasi Recovered ke- $i$. Sehingga

$$
N=N_{i}=S_{i}+I_{i}+R_{i} .
$$

Akan dihitung nilai $k_{1}, k_{2}, k_{3}, k_{4}$ dari sub populasi $S, I, R$. Adanya nilai $k_{1}$ dalam persamaan adalah untuk menentukan $k_{2}$, nilai $k_{2}$ untuk menghitung $k_{3}$ dan seterusnya. Berikut langkah pengerjaan metode Runge Kutta Orde 4.

Tahap 1.

$$
\begin{aligned}
k_{1, S} & =f\left(t_{i}, S_{i}\right)=\Lambda-\Lambda u_{i}-\beta\left(1-u_{i}\right) \frac{I_{i}}{N} S_{i}-\mu S_{i}, \\
k_{1, I} & =f\left(t_{i}, I_{i}\right)=\beta\left(1-u_{i}\right) \frac{I_{i}}{N} S_{i}-\mu I_{i}-\mu_{t} I_{i}-\alpha I_{i}, \\
k_{1, R} & =f\left(t_{i}, R_{i}\right)=\Lambda u_{i}+\alpha I_{i}-\mu R_{i} .
\end{aligned}
$$

Tahap 2.

$$
\begin{aligned}
k_{2, S} & =f\left(t_{i}+\frac{1}{2} h, S_{i}+\frac{1}{2} h k_{1, S}\right), \\
k_{2, I} & =f\left(t_{i}+\frac{1}{2} h, I_{i}+\frac{1}{2} h k_{1, I}\right), \\
k_{2, R} & =f\left(t_{i}+\frac{1}{2} h, R_{i}+\frac{1}{2} h k_{1, R}\right) .
\end{aligned}
$$

Tahap 3.

$$
\begin{aligned}
k_{3, S} & =f\left(t_{i}+\frac{1}{2} h, S_{i}+\frac{1}{2} h k_{2, S}\right), \\
k_{3, I} & =f\left(t_{i}+\frac{1}{2} h, I_{i}+\frac{1}{2} h k_{2, I}\right), \\
k_{3, R} & =f\left(t_{i}+\frac{1}{2} h, R_{i}+\frac{1}{2} h k_{2, R}\right) .
\end{aligned}
$$

Tahap 4.

$$
\begin{aligned}
k_{4, S} & =f\left(t_{i}+h, S_{i}+h k_{3, S}\right), \\
k_{4, I} & =f\left(t_{i}+h, I_{i}++h k_{3, I}\right), \\
k_{4, R} & =f\left(t_{i}+h, R_{i}+h k_{3, R}\right) .
\end{aligned}
$$

Kemudian substitusikan nilai $k_{1}, k_{2}, k_{3}, k_{4}$ yang telah diperoleh untuk setiap sub populasi ke fungsi solusi dari metode Runge Kutta orde 4. Setelah proses diskritisasi tahap 1 sampai tahap 4, maka dibentuk persamaan berikut.

$$
\begin{aligned}
S_{i+1} & =S_{i}+\frac{h}{6}\left(k_{1, S}+2 k_{2, S}+2 k_{3, S}+k_{4, S}\right), \\
I_{i+1} & =I_{i}+\frac{h}{6}\left(k_{1, I}+2 k_{2, I}+2 k_{3, I}+k_{4, I}\right), \\
R_{i+1} & =R_{i}+\frac{h}{6}\left(k_{1, R}+2 k_{2, R}+2 k_{3, R}+k_{4, R}\right) .
\end{aligned}
$$


Persamaan costate yang terdapat pada Persamaan (3.6) diselesaikan menggunakan skema mundur Runge Kutta orde 4. Dengan menggunakan tahapan metode Runge Kutta orde 4 serupa dengan penyelesaian pada persamaan state diperoleh langkahlangkah sebagai berikut.

\section{Tahap 1.}

$$
\begin{aligned}
& k_{1, S}=f\left(t_{i}, \lambda_{S i}\right)=\lambda_{S i} \mu+\left(\lambda_{S i}-\lambda_{I i}\right) \beta\left(1-u_{i}\right) \frac{I_{i}}{N}, \\
& k_{1, I}=f\left(t_{i}, \lambda_{I i}\right)=-1+\lambda_{I i}\left(\mu+\mu_{t}+\alpha\right)+\left(\lambda_{S i}-\lambda_{I i}\right) \beta\left(1-u_{i}\right) \frac{S_{i}}{N}-\lambda_{R i} \alpha, \\
& k_{1, R}=f\left(t_{i}, \lambda_{R i}\right)=\lambda_{R i} \mu .
\end{aligned}
$$

\section{Tahap 2.}

$$
\begin{aligned}
k_{2, S} & =f\left(t_{i}-\frac{1}{2} h, \lambda_{S i}-\frac{1}{2} h k_{1, S}\right), \\
k_{2, I} & =f\left(t_{i}-\frac{1}{2} h, \lambda_{I i}-\frac{1}{2} h k_{1, I}\right), \\
k_{2, R} & =f\left(t_{i}-\frac{1}{2} h, \lambda_{R i}-\frac{1}{2} h k_{1, R}\right) .
\end{aligned}
$$

Tahap 3.

\section{Tahap 4.}

$$
\begin{aligned}
k_{3, S} & =f\left(t_{i}-\frac{1}{2} h, \lambda_{S i}-\frac{1}{2} h k_{2, S}\right), \\
k_{3, I} & =f\left(t_{i}-\frac{1}{2} h, \lambda_{I i}-\frac{1}{2} h k_{2, I}\right), \\
k_{3, R} & =f\left(t_{i}-\frac{1}{2} h, \lambda_{R i}-\frac{1}{2} h k_{2, R}\right) .
\end{aligned}
$$

$$
\begin{aligned}
k_{4, S} & =f\left(t_{i}-h, \lambda_{S i}-h k_{3, S}\right), \\
k_{4, I} & =f\left(t_{i}+h, \lambda_{I i}+h k_{3, I}\right), \\
k_{4, R} & =f\left(t_{i}+h, \lambda_{R i}+h k_{3, R}\right) .
\end{aligned}
$$

Setelah proses diskritisasi tahap 1 sampai tahap 4, maka dibentuk persamaan berikut.

$$
\begin{aligned}
S_{i-1} & =S_{i}-\frac{h}{6}\left(k_{1, S}+2 k_{2, S}+2 k_{3, S}+k_{4, S}\right), \\
I_{i-1} & =I_{i}-\frac{h}{6}\left(k_{1, I}+2 k_{2, I}+2 k_{3, I}+k_{4, I}\right), \\
R_{i-1} & =R_{i}-\frac{h}{6}\left(k_{1, R}+2 k_{2, R}+2 k_{3, R}+k_{4, R}\right) .
\end{aligned}
$$

Selanjutnya hasil diskritisasi Persamaan (3.13) dan (3.14) diselesaikan dengan program Scilab.

\subsection{Analisis Simulasi Numerik}

Simulasi numerik diselesaikan dengan menggunakan program scilab. Model penyebaran penyakit TB dengan menggunakan kontrol vaksinasi dan pengobatan disimulasikan pada saat populasi awal $\left(S_{0}, I_{0}, R_{0}\right)$ adalah $(41.572,4.655,3.730)$. Untuk simulasi numerik, parameter yang digunakan disajikan pada Tabel 1. 
244 Fajrin Nursetya Desi dkk.

\begin{tabular}{|c|c|c|c|}
\hline Parameter & Deskripsi & Nilai & Sumber \\
\hline \hline$\Lambda$ & Banyaknya kelahiran alami & 90.913 & {$[7]$} \\
\hline$\mu$ & Laju kematian alami & 0,118 & {$[7]$} \\
\hline$\mu_{t}$ & Laju kematian akibat penyakit & 0,033 & {$[8]$} \\
\hline$\alpha$ & Laju kesembuhan alami & 0,00032 & {$[3]$} \\
\hline$\beta$ & Laju penularan penyakit & 0,0097 & {$[3]$} \\
\hline
\end{tabular}

Tabel 1. Nilai parameter model penyakit TB

Berdasarkan Tabel 1, nilai parameter tersebut disubstitusikan ke Persamaan (3.7) sampai Persamaan (3.12) yang nantinya disimulasikan secara numerik. Berdasarkan hasil simulasi tersebut, maka diperoleh grafik sebagai berikut.

\subsubsection{Subpopulasi Susceptible dan Interpretasinya}

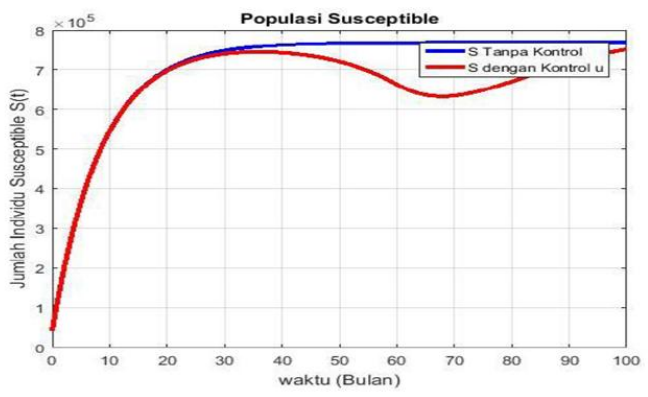

Gambar 2. Grafik perubahan banyaknya individu Susceptible dengan kontrol dan tanpa kontrol

Berdasarkan Gambar 2, dapat dilihat bahwa pada bulan ke-0 sampai bulan ke20 jumlah individu susceptible dengan adanya kontrol sama dengan jumlah individu susceptible tanpa kontrol. Kemudian pada bulan ke-21 sampai bulan ke-69 jumlah individu susceptible berkurang, karena individu subpopulasi susceptible berpindah ke subpopulasi recovered karena adanya penyembuhan. Pada bulan ke-70 individu susceptible kembali naik hingga bulan ke-100.

\subsubsection{Subpopulasi Infective dan Interpretasinya}

Berdasarkan Gambar 3, dapat dilihat bahwa jumlah individu infective lebih efektif mengalami penurunan dengan adanya kontrol dibandingkan dengan tanpa adanya kontrol. Jumlah individu infective dengan pemberian kontrol mengalami penurunan secara signifikan pada awal periode hingga mencapai 0 pada sekitar bulan ke-30 sampai bulan ke-100, berarti individu infective tidak ada yang terinfeksi penyakit. 


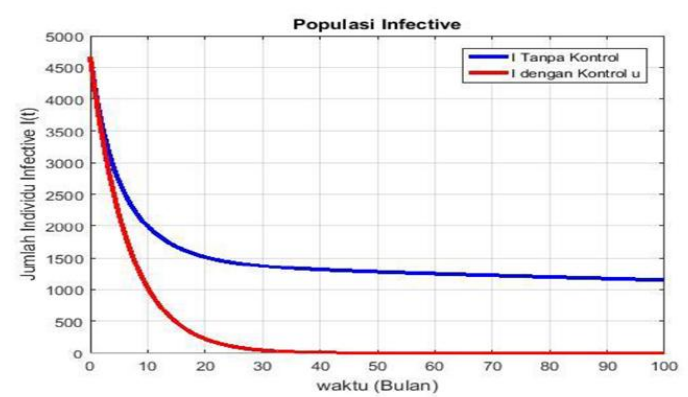

Gambar 3. Grafik perubahan banyaknya individu Infective dengan kontrol dan tanpa kontrol

\subsubsection{Subpopolasi Recovered dan Interpretasinya}

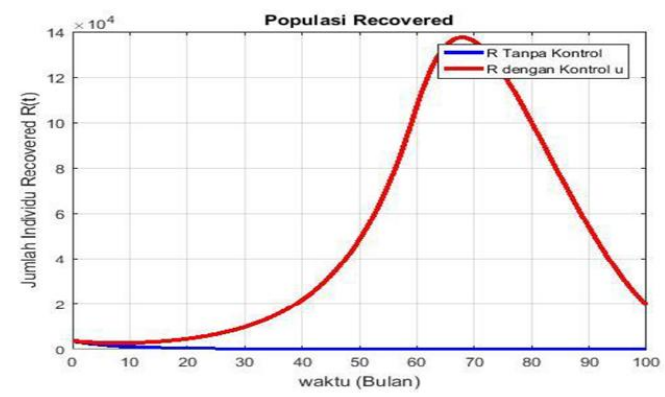

Gambar 4. Grafik perubahan banyaknya individu Recovered dengan dan tanpa kontrol

Berdasarkan Gambar 4, dapat dilihat bahwa adanya kontrol vaksinasi lebih efektif meningkatkan subpopulasi recovered hingga mencapai lebih dari 130000 individu. Sedangkan tanpa kontrol vaksinasi individu menurun hingga mencapai 0 individu.

\subsubsection{Kontrol $u_{1}$ dan Interpretasinya}

Berdasarkan Gambar 5, kontrol $u_{1}$ yang diberikan pada awal periode adalah minimum sebesar 0 meningkat hingga sekitar 0,23 pada bulan ke-62, kemudian mengalami turun hingga 0 pada akhir periode.

\subsubsection{Kontrol $u_{2}$ dan Interpretasinya}

Pada Gambar 6, kontrol $u_{2}$ yang diberikan di awal periode adalah maksimum yaitu sebesar 1 hingga bulan ke-59, kemudian turun hingga 0 di akhir periode. 


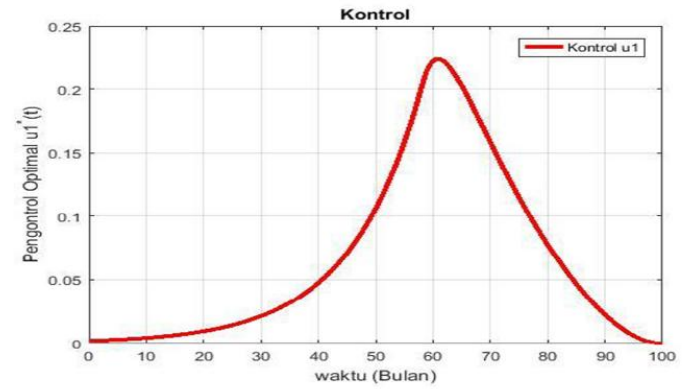

Gambar 5. Grafik Kontrol $u_{1}$

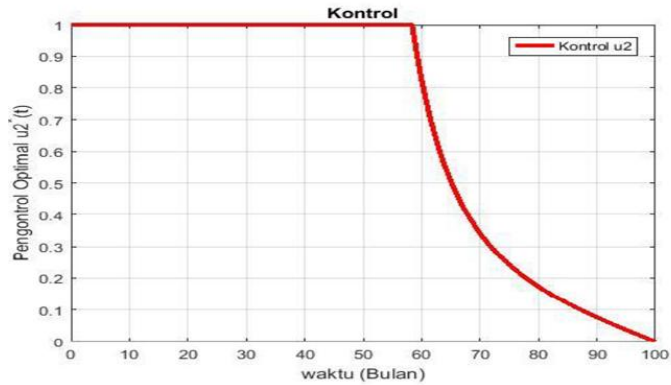

Gambar 6. Grafik Kontrol $u_{2}$

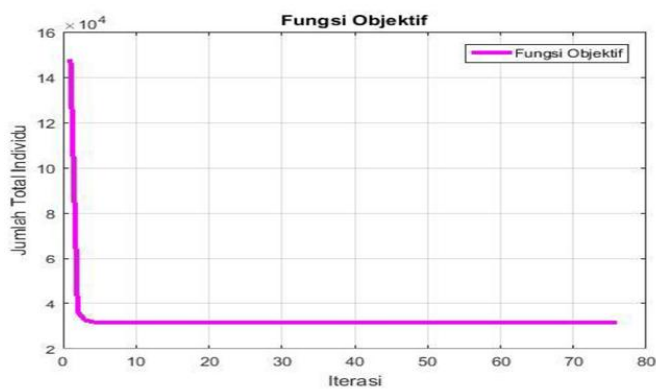

Gambar 7. Grafik fungsi objektif

\subsubsection{Fungsi Objektif dan Interpretasinya}

Pada Gambar 7, kontrol $u_{1}$ dan $u_{2}$ yang diberikan menyebabkan fungsi tujuan yang awalnya bernilai lebih dari 140000 turun hingga sekitar 30000 pada iterasi ke-78. Dapat disimpulkan bahwa hal tersebut dikarenakan adanya kontrol $u_{1}$ dan $u_{2}$ yang meminimumkan fungsi objektif. 


\section{Kesimpulan}

(1) Model epidemi tipe SIR dengan penambahan kontrol vaksinasi dan pengobatan pada penyebaran penyakit TB adalah:

$$
\begin{aligned}
\frac{d S}{d t} & =\Lambda-\Lambda u_{1}-\beta\left(1-u_{2}\right) \frac{I}{N} S-\mu S, \\
\frac{d I}{d t} & =\beta\left(1-u_{2}\right) \frac{I}{N} S-\mu I-\mu_{t} I-\alpha I, \\
\frac{d R}{d t} & =\Lambda u_{1}+\alpha I-\mu R .
\end{aligned}
$$

(2) Berdasarkan hasil analisis, diperoleh kontrol dan sistem yang optimal, yaitu:

$$
\begin{aligned}
& u_{1}^{*}(t)=\min \left\{1 ; \max \left\{0, \frac{\lambda_{1} \Lambda-\lambda_{3} \Lambda}{c_{1}}\right\}\right\}, \\
& u_{2}^{*}(t)=\min \left\{1 ; \max \left\{0, \frac{-\lambda_{1} \beta \frac{I}{N} S+\lambda_{2} \beta \frac{I}{N} S}{c_{2}}\right\}\right\} .
\end{aligned}
$$

\section{Daftar Pustaka}

[1] World Health Organization, 2019, Global Tuberculosis Report

[2] Naidu, 2002, D. S., Optimal Control Systems, CRC Press, New York

[3] Fredlina, K.Q., T. B. Oka, dan I. M. Dwipayana, 2012. SIR (Susceptible, Infectious, Recovered) Model for Tuberculosis Disease Transmission, J. Matematika Vol. 1(1): 52 - 58

[4] Utari, I, A, P, A., Kontrol Optimal Upaya Pengobatan Penyakit Campak Menggunakan Model Endemi SIR, Jurnal Matematika Vol. 9(2): $94-100$

[5] N. Anggriani, A. Supriatna, B. Subartini, R. Wulantini, 2015, Kontrol Optimum pada Model Epidemik SIR dengan Pengaruh Vaksinasi dan Faktor Imigrasi, Jurnal Matematika Integratif Vol. 11 No 2: 111 - 118

[6] Setiawan, 2012, Kontrol Optimal Penyebaran Tuberkulosis dengan Exogenous Reinfection, Tesis Magister, tidak diterbitkan, Fakultas MIPA, Universitas Indonesia, Depok

[7] Data Kalbarprov. 2018. http://data.kalbarprov.go.id/dataset/jumlahkelahiran- menurut-jenis-kelamin-dan-kab-kota-prov-kalbar-tahun-2018 [diakses 8 April 2020]

[8] Dinas Kesehatan Kalimantan Barat, 2018 